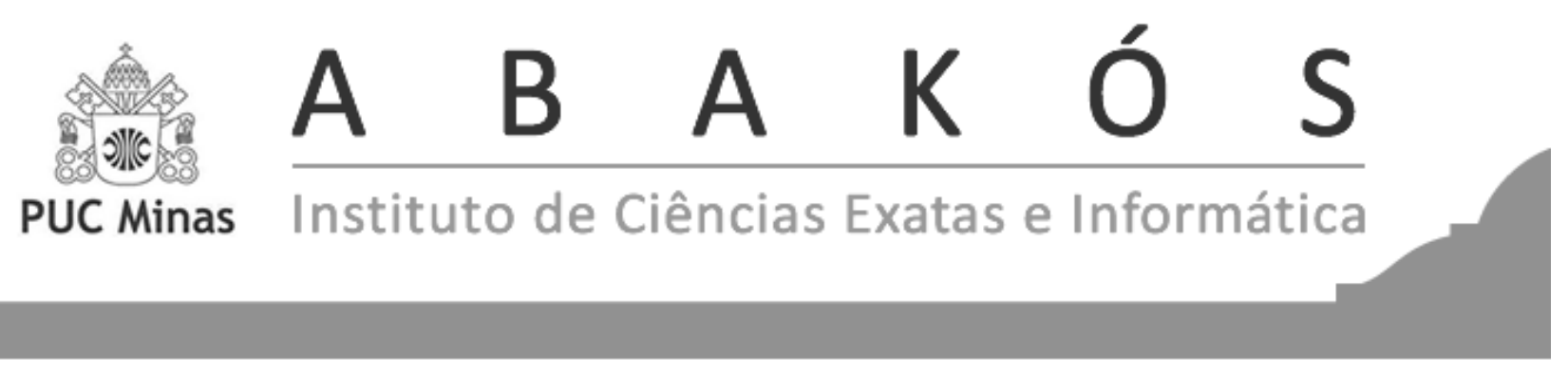

Licença Creative Commons Attribution-NonCommercial-NoDerivs 3.0 Unported

\title{
Editorial
}

Around the IV century BC, the Greeks already knew that the brain is the responsible for the sensations. Hippocrates (460-379 BC) went further to say that the brain would be the locus of intelligence. Claudio Galeno, in the second century AD, in a study of anatomy and physiology, was the first to associate intelligence and memory, and to give the brain the role of cognition medium. Carl Wernicke (1848-1905), a German neuropathologist, was a pioneer in studies of parts of the brain responsible for speech and language comprehension (auditory area). More recently, Johnson and Myklebust (1987) stated that learning depends on good operating condition of the peripheral nervous system, so that the brain can receive and consolidate information.

Similar studies in the field of neuroscience have been exploring new possibilities for the investigation of the complex relationships between individual and society. Neuroscience and cognitive science are fields for interdisciplinary studies not only of brain processes and neural networks, but as well as their interactive relationships with the physical, social and cultural environment. The links between neuroscience and education are narrowing increasingly. The learning process takes place during the organization of experiences in increasing degrees of complexity, and therefore there is a concern among educators in building competence and developing skills, combining knowledge about brain functioning in its various dimensions: biological, motor, emotional, psychological and social.

This edition makes room for such interdisciplinary approaches. The first paper presents a new methodology to assist education of basic electricity by appling serious games, in order to make simulations more attractive and entertaining. The second paper describes a proposal for the use of ontologies in the Knowledge Discovery process in Databases (KDD). The third article presents neuroscience experiments in teaching and learning. The fourth paper presents the mapping of scientific articles that deal with topics related to mathematics literacy and teacher training in the early years. The final text mentions again the application of gamification concepts in education and teaching.

Interdisciplinary studies in education and neuroscience give a sample of how essential are the interactions between different areas of knowledge so that they can deepen the knowledge of a world increasingly connected and complex.

This is our proposal, this is our mission.

Keep on with us!

\section{Editors of Abakós}




\section{Editorial}

Por volta do século IV a.C., os gregos já sabiam que o cérebro é o responsável pelas sensações. Hipócrates (460-379 a.C.) foi além ao afirmar que o cérebro seria o locus da inteligência. Cláudio Galeno, no século II d.C., em estudos sobre anatomia e fisiologia, foi o primeiro a associar inteligência e memória e atribuir, ao cérebro, o papel de sede das faculdades cognitivas. Carl Wernicke (18481905), neuropatologista alemão, foi pioneiro nos estudos das partes do cérebro responsáveis pela fala e compreensão da linguagem (área auditiva). Mais recentemente, Johnson e Myklebust (1987) afirmaram que a aprendizagem depende de condições adequadas de funcionamento do sistema nervoso periférico para que o cérebro possa receber e consolidar informações.

Estudos semelhantes, na área da neurociência, têm explorado novas possibilidades para a investigação das relações complexas entre indivíduo e sociedade. A neurociência e as ciências cognitivas constituem campos para estudos interdisciplinares não só dos processos cerebrais e das redes neurais, como também de suas relações interativas com o ambiente físico, social e cultural. Estreitam-se, cada vez mais, os laços entre a neurociência e a educação. O processo de aprendizagem ocorre durante a organização de experiências em graus crescentes de complexidade e, por isso, há preocupação dos educadores em construir competências e desenvolver habilidades, aliando conhecimentos sobre o funcionamento do cérebro em suas diversas dimensões: biológica, motora, emocional, psicológica e social.

Esta edição abre espaço para tais abordagens interdisciplinares. O primeiro texto apresenta uma nova metodologia para auxiliar o ensino de eletricidade básica mediante aplicações de serious games, tornando simulações mais atraentes e lúdicas. O segundo texto descreve uma proposta de uso de ontologias no processo de Knowledge Discovery in Database (KDD). O terceiro texto apresenta algumas experiências da neurociência em processos de ensino e aprendizagem. O quarto texto apresenta o mapeamento de artigos científicos que tratam de temas relativos à alfabetização matemática e à formação do professor nos anos iniciais. O último texto retoma a aplicação de conceitos de gamification (ludificação) na educação e no ensino.

Os estudos interdisciplinares na educação e na neurociência dão uma amostra de como são essenciais as interações entre as diversas áreas do saber para que se possa aprofundar o conhecimento sobre um mundo cada vez mais conectado e complexo.

Essa é a nossa proposta, essa é a nossa missão.

Continue conosco!

\section{Editores da Abakós}

